not a set of concepts or rules but something to be discovered personally and lived. Dr. Marjorie Reeves shows that the really mature man or woman is one who takes responsibility. The young must be brought up against hard and moral decisions in terms of what is known of the universe and their own natures. The first chapter is by the dean of the Institute of Education, University of London, Prof. W. R. Niblett, who deals in a wise, logical and succinct manner with a statement of the problems of moral education to-day.

W. L. SUMNER

\section{MAMMALS OF THE U.S.S.R.}

Mammals of Eastern Europe and Northern Asia

By S. I. Ognev. Vol. 1: Insectivora and Chiroptera. Pp. $487+$ xv. 98s.; 14 dollars. Vol. 2: Carnivora (Fissipedia). Pp. 590+xv. 110s.; 15.50 dollars. Translated from the Russian. (Jerusalem: Israel Program for Scientific Translations, 1962-63.)

Mammals of U.S.S.R. and Adjacent Countries

By S. I. Ognev. Vol. 3: Carnivora (Fissipedia and Pinnipedia). Translated from the Russian. Pp. 641 +xv. (Jerusalem: Israel Program for Scientific Translations, 1962.) 110s.; 15.50 dollars.

THESE first three volumes of Ognev's massive work on the mammals of the U.S.S.R. appeared in 1928, 1931 and 1935. The four subsequent volumes, translations of three of which have been promised from the same source, deal with the rodents and appeared in 1940, 1944, 1947 and 1950, the last a year before Ognev's death. The series has been continued by a volume on the Cetacea by Tomilin in 1957 and one on the Artiodactyla by Heptner et al. in 1961. However highly we rate these early volumes it is inevitable that they are to some extent out of date and therefore before we consider the usefulness of these translations it is necessary to consider to what extent the subject-matter has been superseded by more recent publications. The sections on the Insectivora and Fissipedia have, in fact, been largely superseded by the works of Strogonov ${ }^{1}$ on these groups, albeit confined to Siberia. No comparable works exist on the Chiroptera and Pinnipedia. Strogonov's works deal in an up-to-date manner with most of the ground covered by Ognev and it is to be hoped that translations will become available before they in turn are out of date.

The taxonomy of Ognev in these three volumes is typical of its period. The trinomial nomenclature that did so much to reduce the chaos of late nineteenth-century mammalian taxonomy, culminating in such works as Miller's Catalogue of the Mammals of Western Europe, had by 1930 lost sight of its raison d'être and led the subject into an impasse of confusion little better than that from which it had arisen. The taxonomic treatment steps from genus to sub-species (and even "natios" with tetranomina) with little indication that anything exists between these. The sub-species only are numbered (1-86 in the Insectivora alone, up to 308 by the end of volume 3 ), and most of the biological data are given, in a rather discursive style without sub-headings, under the typical or first-mentioned sub-species. (In his subsequent volumes Ognev progressively adopted the species as the principal unit.) The biological and ecological data are mainly qualitative and as might be expected are derived primarily from European Russia.

For the mammalogist working on palæarctic groups, whether from the point of view of taxonomy or ecology, these translations will be invaluable. As reference works for the non-specialist they represent the only available detailed accounts in English of these groups in the U.S.S.R., and as such must be hailed as a valuable addition to any zoological reference library. But it is to be hoped that the more recent literature will also be made available in the same way.
The typography is excellent and the original pagination is indicated in the margin. The illustrations are reduced. by 25 per cent and have suffered considerably in the process, some, for example a drawing of a bull fur-seal on p. 341 of volume 3 , to the extent of being completely unrecognizable. An index to all three volumes appears at the end of each, but alas in each case one page is missing and two others have been transposed.

\section{G. B. Corbet}

2 Strogonov, S. V., Animals of Siberia: Insectivores (Moscow, 1957); Animals of Siberia: Carnivores (Moscow, 1962).

\section{IMMUNITY TO PARASITIC PROTOZOA}

\section{Immunity to Protozoa}

Edited by Prof. P. C. C. Garnham, Dr. A. E. Pierce and Dr. I Roitt. (A Symposium of the British Society for Immunology.) Pp. xii +359. (Oxford: Blackwell Scientific Publications, 1963.) 70s. net.

THIS book will be welcomed by every parasitologist, whether he is especially interested in the Protozoa or not. It gives us, in book form, the papers presented at a symposium on diseases caused by parasitic Protozoa, which was held by the British Society for Immunology at the Middlesex Hospital Medical School in June, 1963, and, as Dr. Coombs says in his preface, there is no other book at present in print which is devoted entirely to this subject. In order that the main theme should not be obscured, serological methods have not usually been included, although a notable exception to this is the chapter on serological tests in toxoplasmosis by Dr. J. D. Fulton.

It is, of course, impossible to give, in a short review, an adequate idea of the wealth of detailed information given by the book. To be fully appreciated it must be read. It begins with a masterly introduction by Prof. Garnham who considers in turn the histological basis of immunity to protozoal diseases, immunity to them and its serological and other reactions and natural immunity, and touches on pretty well every aspect of the subject. His brief account of its history reminds us that immunity to malaria was recognized even in medieval times and that the later work of Ehrlich, Metchnikoff, Koch, Christophers, Sergent and others developed our knowledge until more precise investigations were possible.

The next chapter is by Dr. W. H. Taliaferro, who dealt, as early as 1929, with a much wider field in his classic entitled The Immunology of Parasitic Infections. Here he discusses the cellular and humoral factors which operate in immunity to Protozoa-a subject on which he has done a great deal of pioneer work. Then follows a chapter on "Latent Infections and Premunition" by Edmond Sergent, another pioneer whose work began in the first quarter of the present century. Prof. Maegraith then completes Part 1 of the book, entitled "Introductory Concepts of Immunity to Protozoa", with a chapter on pathogenesis and pathogenic mechanisms with special reference to amœbiasis and malaria.

Part 2 of the book is devoted to immunity to protozoan parasites of the blood, the malarial parasites, the species of Babesia and Theileria of cattle and Trypanosoma being dealt with by experts who have specialized in the study of these genera. The veterinarian, as well as the medical man, will find much of interest in these chapters.

Part 3 of the book discusses immunity to Protozoa parasitic in other tissues, the species here considered being, on one hand, Leishmania and Toxoplasma which cause generalized infections and, on the other, species which cause Iocalized infections, those considered here being the coccidia parasitic in the food canals of the fowl, turkey and rabbit and Trichomonas foetus, which infects the genital tract of cattle. Here also the veterinarian will find much 